\title{
The Byelorussian Impact on Karaite and Yiddish
}

\author{
BY \\ P. WEXLER
}

During the 11-14th centuries, no less than four Kipčak Turkic speaking groups settled in Eastern Europe: (a) the Tatars and Karaites settled in Byelorussian- and Ukrainian-speaking territories of the Grand Duchy of Lithuania in the 14th century; (b) Kipčak-speaking members of the Armenian Church settled in Galicia and Podolia beginning with the 11 th century; ${ }^{1}$ (c) the Cumans settled in Hungary in the 11th century. ${ }^{2}$ Of these four groups, only the Karaites, descended from a Jewish sect founded in the 8th century in Iraq which rejects the authority of the oral law, have preserved their speech up to the present - though assimilation to Russian and other Soviet languages is now proceeding apace. ${ }^{3}$ The Tatars and Armenians apparently assimilated by the 16 th century to Byelorussian and Ukrainian, while the Cumans became absorbed into the Hungarian speech community by the 18 th century. The Byelorussian Tatars have long been the object of scholarly investigation. While their language disappeared without any significant written documentation, the Byelorussian Tatars are important to Byelorussian linguistics because they wrote Byelorussian in an Arabic-derived script from the 17 th century up to the early 20th century, which allows us to reconstruct many features of the spoken language not systematically reflected in the traditional Cyrillic and Latin orthographies. ${ }^{4}$

The language of the Karaite community in Eastern Europe has been studied almost exclusively from the Turkological point of view. ${ }^{5}$ This is not surprising, since Karaite is of considerable interest to Turkologists for a number of reasons: (1) Karaite is the sole survivor of Eastern European Kipčak dialects (and the sole extant form of Karaite itself since the indigenous Crimean dialects of the language became extinct in the 19 th century); ${ }^{6}$ (2) Karaite is one of the few Turkic languages spoken exclusively by a non-Muslim population and hence preserves much original lexicon broadly replaced in other Turkic languages by Arabic and Persian; (c) Eastern European Karaite offers a chronological framework for dating the Arabic and Persian component in Turkic languages; (d) Karaite is the only Turkic language receptive to enrichment from Hebrew, the liturgical and literary language of the Karaites, which has contributed considerably to the de-Turkicization of Karaite lexicon and syntax, especially in its non-spoken forms. While Turkologists have cited the existence of Slavic elements in Karaite and have correctly identified Slavic influence as a further factor, alongside Hebrew, contributing to the de-Turkicization of the language, there are no systematic studies 
of the Slavic impact. ${ }^{7}$ Moreover most discussions are woefully imprecise about the sources of the Slavic components in Karaite. For example, the most recent lexicographical study, the Karaimskorussko-pol'skij slovar' (Moscow 1974), edited by N. A. Baskakov, A. Zajączkowski and S. M. Szapszał, is especially negligent in identifying Slavic source components, e.g. šavec $(\mathrm{Tr})^{8}$ 'shoemaker' is not marked as Slavic (see Byelorussian šaviec) while praunuk (Tr) 'great grandson' is called "Slavic" rather than Byelorussian.

In view of the inadequate studies of Slavicization in Karaite, it would be useful to explore the impact on Karaite of Slavic languages, especially Byelorussian, and to a lesser extent, Polish and Ukrainian. However, it seems to us that the Slavicization of Karaite ought not to be studied in isolation from the other coterritorial minority languages which have also been exposed to Slavic enrichment. Hence, in order to explore areal implications of Slavicization, we will contrast the Slavicization of Karaite with that of Yiddish, and when evidence is available, with Colonial German dialects spoken in a Slavic milieu. ${ }^{9}$ A comparative exploration of these three languages is attractive for two reasons: (1) all three languages have been coterritorial in Eastern Europe since the 14th century; (2) while the three languages have been exposed to the identical Slavic source languages, they have differed markedly in their receptivity to and patterns of integration of Slavic. ${ }^{10}$ Though the differential impact of Slavic on Yiddish and German has been subjected to a thorough study by Uriel Weinreich ${ }^{11}$ and though many of the Byelorussian minority languages were briefly included in numerous discussions of areal drift by Roman Jakobson, ${ }^{12}$ we know of no comparison of the Slavic impact on the two Jewish languages - Karaite and Yiddish. ${ }^{13}$

Byelorussian Karaite and Yiddish data will be presented below under the following four headings: (1) dialectal origin of Slavic components in Karaite and Yiddish; (2) relexification of Karaite and Yiddish elements (native and non-native) to Slavic surface cognates; (3) recalibration of Karaite and Yiddish resources along Slavic models of discourse; (4) integration of Slavic verbal stems in Karaite and Yiddish.

\section{Dialectal origin of Slavic components in Karaite and Yiddish}

Many observers have claimed that Slavic elements in Karaite dialects are typically of regional character, e.g. the Halyc dialect is exposed to Ukrainian and Polish, Trakai to Byelorussian and Polish, while Luck was particularly influenced by Russian and Ukrainian. ${ }^{14}$ For example, grarbuz (Tr) 'watermelon' < Byelorussian harbuz (vs. Polish, Russian arbuz: see Turkish karpuz); kanople (Tr) 'flax' < Byelorussian kanopli (no singular) (vs. Polish konopie: see also Yiddish arbuz and kanopl'es (pl.) 'hemp' - the latter term also reflecting a Byelorussian rather than Polish source). While 'tea' in the Trakai dialect is grarbata (see Polish herbata, Byelorussian dialectal harbata), Halyč has čaj (Ukrainian čaj: see also Turkish 
cay). Nevertheless, the two Karaite dialects of Trakai and Halyč may differ in their exposure to a common Polish source of enrichment. For example, Polish cegła is attested only in Trakai dialect. According to Kowalski, ${ }^{15}$ the Trakai and Halyč dialects have become further differentiated due to exposure to dissimilar Slavic influences, e.g. Byelorussian influence in Trakai has introduced into that dialect the palatalization of consonants before $e$, while the absence of this feature in coterritorial Ukrainian dialects accounts for the absence of this feature in the Halyč dialect of Karaite. ${ }^{16}$ The Slavic component in Colonial German dialects is also of a typically regional character. ${ }^{17}$

A curious feature of Karaite Slavicisms is the apparent merger of two Slavic source languages in the Karaite of both Halyč and Trakai. For example, in farbovat ét- 'to paint' ( $\mathrm{Tr}, \mathrm{Ha}$ ), the Slavicism farbovat suggests both Polish farbowac and Ukrainian farbuvaty (see Byelorussian farbavać), unless we are dealing here with a subsequent partial Ukrainianization of a Karaite Polonism. Yiddish dialects spolken in these areas are equally exposed to multiple Slavic source languages, e.g. Byelorussian Yiddish padloge 'floor' which suggests both Polish podłoga and Byelorussian padłoha; $;^{8}$ Trakai Karaite has podlagra.

Of all the Eastern languages in contact with Slavic, only Yiddish dialects show both a regional and a non-coterritorial Slavic imprint. ${ }^{19}$ As examples of regionalisms, Northeast Yiddish (e.g. Vilna) and the standard language have dlot 'chisel' vs. Southeast Yiddish (e.g. Luck) dolete < Polish dłoto and Ukrainian doloto, Byelorussian dołata respectively; Northeast Yiddish podkeve 'horseshoe' (standard Yiddish potkeve) < Polish podkowa vs. Southeast Yiddish pidkove < Ukrainian pidkova. ${ }^{20}$ Polish Yiddish dialects have cmenter, cminter, cmenta $\check{z}^{21}$ '(Christian) cemetery' $<$ Polish cmentarz vs. Ukrainian (and standard) Yiddish cvinter < Byelorussian ćvintar, Ukrainian cvyntar; Polish Yiddish modl(')en zix '(Christians) pray' < Polish modlić się vs. Ukrainian and standard Yiddish molyen zix < Ukrainian molytysja. On the other hand, in counterdistinction to Karaite dialects, many Slavicisms in Yiddish are of non-local origin. M. Sulman has shown that $10 \%$ of the Slavic elements in "Russian" Yiddish are of Polish origin while over $50 \%$ of the Slavic elements in "Polish" Yiddish are from Ukrainian, Byelorussian or Russian. ${ }^{22}$ For example, Polish (and standard) Yiddish have ozere 'lake' ( $<$ Southwest Byelorussian oziera) vs. Polish jezioro; demb (also standard Yiddish and a back formation from the Polish plural dęby), domb, $d u b$ 'oak' vs. Polish $d a b$, Byelorussian $d u b .^{23}$ As the examples above indicate, the standard language is eclectic in its canonization of Slavicisms, e.g. potkeve < Polish alongside cvinter < Byelorussian, Ukrainian. Yiddish also tolerates doublets of diverse Slavic origins, e.g. hoyl 'bare, pure' (< Czech holý) goln (zix) 'shave', gole 'pure, sheer' $(<$ Polish golic [się], goły). The cumulative continuity of the Slavic loans through time frees Yiddish to some degree from a purely regional Slavic imprint. It is presently unclear to what extent Karaite Slavicisms reflect distinct chronological strata (see fn. 32). 


\section{Relexification of Karaite and Yiddish elements to Slavic surface cognates}

An interesting index of Karaite and Yiddish independence from the coterritorial Slavic environment is the disinclination to relexify native resources to the Slavic surface cognates. This disinclination has not been adequately explored. The fact that examples of relexification in both languages are relatively rare suggests that there are limits to the Slavicization of the Karaite and Yiddish lexicons, even though loan translations on Slavic models and outright borrowings from Slavic are both quite common in the two target languages. In Karaite, relexification could primarily affect native Turkic and Persian elements since these are the components likely to be shared with Slavic lexicons; in Yiddish, the components to be relexified are exclusively native Germanic, international, and Western Slavic elements which are occasionally replaced by the Eastern Slavic cognates in the Ukraine, Byelorussia and Russia. For example, Karaite šaxlar $(\mathrm{Ha})$ 'chess' requires a plural suffix (-lar) in imitation of the Slavic pattern, see Byelorussian šaxmaty, Ukrainian šaxy (vs. Turkish satranc < Persian šäträndž: but Yiddish šaxšpil is not affected by the Slavic languages); Karaite kaštan (Tr) 'chestnut' (ultimately from Greek) is borrowed from Byelorussian kaštan, Polish kasztan vs. Karaite késtané, késténé (Crimean dialect) (see Turkish kestane: Yiddish kest is not relexified). See also Karaite grarbuz (Tr) 'watermelon' < Byelorussian harbuz vs. Turkish karpuz discussed above. Occasionally, Slavicization may result in the creation of doublets rather than in the replacement of the original form, e.g. Karaite marmur, marmor ( $\mathrm{Ha})$ 'marble' suggest a Byelorussian, Polish or Ukrainian marmur while marmar ( $\mathrm{Tr}, \mathrm{Ha}$ ) is reminiscent of Greek marmaron (see Turkish mermer).

Relexification very often does not take place even though a Slavic surface cognate is readily available, e.g. Karaite jovél (Ha) 'jubilee' $1<$ Hebrew yovel; Hebrew examples are cited in modern Israeli pronunciation) vs. Polish jubileusz, Byelorussian jubilej, Ukrainian juvilej; xazna (Tr, Ha) 'treasury' vs. Polish, Ukrainian, Byelorussian kazna (see Turkish hazine); zafran (Tr, Ha) 'saffron' (< Persian $z \ddot{a}^{\prime}$ färan) vs. Polish szafran, Byelorussian šafran (see Turkish safran); tütün (Tr) 'tobacco, smoke' vs. Polish tyton,, Byelorussian tytuń, tutun 'tobacco'.

In Yiddish, we also find only sporadic replacement of native terms by cognate Germanicisms borrowed by the Slavic languages, e.g. Yiddish roybn 'rob, pillage' ( $\sim$ German räuben $>$ rabeven) (based on Byelorussian rabavać), Yiddish retn 'save' ( German retten; the Yiddish term itself may be a recent Germanism) $>$ rateven (based on Byelorussian ratavać). Yiddish resistance to Slavic is shown by the tendency to create a de-Slavicized variant, e.g. rabirn, ratirn. ${ }^{24}$ When the original Yiddish term is lacking, there is no attempt at de-Slavicization, e.g. Yiddish harteven 'temper, harden' (based on Byelorussian hartavać, Polish hartować: see German härten). International vocab- 
ulary in Yiddish may occasionally be adjusted to Slavic norms, e.g. Yiddish universitet 'university' is masculine (as is Byelorussian univiersitet) vs. German Universität feminine.

\section{Recalibration of Karaite and Yiddish resources along Slavic models}

Native Karaite and Yiddish terms are frequently recalibrated according to Slavic patterns of discourse. Examples of Slavic loan translations in Karaite are jérdégi (Ha) 'potato' $<$ native jér 'land, earth' on the model of Polish ziemniak 'potato' < ziemia 'land, earth'; jér isi 'agriculture' (Tr, Ha) = 'land' + 'work' patterned on Ukrainian zemlerobstvo, Russian zemledelije (vs. Turkish ziraat < Arabic); grarbuz 'watermelon' in gъarbuz ber- (Tr) (with the native auxiliary 'give') assumes the meaning 'refuse a male suitor', based on Polish dać arbuza or Ukrainian daty harbuza (where the noun also means 'watermelon'). An example of a Yiddish loan translation is Byelorussian Yiddish barg 'mountain' which acquires the additional meaning of 'attic' on the model of Byelorussian hara 'mountain, attic'.

While both Karaite and Yiddish translate Slavic words and expressions by native elements, the two languages differ in the Slavicization of their common Semitic components. Karaite may have examples of loan translations of Slavic patterns using Semitic elements; HebrewAramaic components in Yiddish seem to retain their original functions more consistently than in Karaite. Possible examples of Hebrew elements in Karaite which have assumed Slavic meanings are darom ( $\mathrm{Tr}, \mathrm{Ha}$ ) 'south' and cafon 'north' (Hebrew darom, cafon); darom acquired the additional meaning of 'noon', possibly in imitation of Byelorussian poŭdzeń, Ukrainian poludne, Polish południe which have both meanings; similarly, cafon also means 'midnight', in imitation of Byelorussian poŭnač, Ukrainian pivnič, Polish pótnoc 'north, midnight'. On the other hand, a number of Turkic languages have a common morpheme for 'noon; south' and 'midnight; north' and the Karaite feature may thus be original and not attributable to Slavic impact (see e.g. modern Turkish gün 'day': güney 'south'). See also discussion of Yiddish farxolemen zix, below, p. 106.

In a number of Karaite periphrastic verbs involving Arabic or Hebrew components and native auxiliaries other than 'do, make', the native auxiliary seems to be chosen in imitation of Slavic practice, e.g. kurban juvut- (Tr, Ha) 'make a sacrifice' (< Arabic qurbān 'sacrifice') uses the auxiliary 'bring, yield', in imitation of the auxiliary in the corresponding Slavic constructions, e.g. Polish składać ofiarę, Russian prinosit' žertvu. Synonymous Yiddish brengen a korbm (< Hebrew korban 'sacrifice') also suggests a Slavic model. Karaite deraša oxu- (Tr) 'deliver a sermon' ( $<$ Hebrew draša 'sermon'), with the auxiliary 'read', imitates Ukrainian čytaty propovid', Russian čitat' propoved' (vs. Polish wygłaszać kazanie) vs. Turkish $v a^{\prime}$ zetmek (< $v a^{\prime} z$ 'sermon' + etmek 'do, make'). ${ }^{26}$ The Yiddish equivalent is non-periphrastic daršn, daršenen. On the other hand, Karaite periphrastic constructions consisting of Semitic loans and the native auxiliaries 'do, make' and 'become' may resist 
Slavicization, e.g. débéxa ét- $(\mathrm{Tr}, \mathrm{Ha})$ 'to sacrifice' (< Arabic đabīha 'sacrifice') shows no Slavic influence. ${ }^{27}$ Occasionally, Hebrew loans retain their derivational properties in Karaite, e.g. Hebrew pilpul 'subtle argumentation, casuistry' $>$ Karaite pilpullanma (Tr, Ha) 'engage in debate' (-la- is the denominative suffix, $-n$ - the middlereciprocal infix, $-m a$ the infinitive marker). The use of the infix $-n-$ is not motivated by Turkish or the Slavic languages which lack a reflexive-middle-reciprocal marker (e.g. Byelorussian abhavarvać, Russian debatirovat', obsuždat'). The model for - $n$ - in Karaite would seem to be the derived verb in Hebrew, hitpalpel, with the prefix hit-, a denominative marker which also denotes reflexive and reciprocal actions. See also Yiddish pilpl 'subtle argumentation', pilpn zix 'split hairs, subtilize' with zix, the reflexive-middlereciprocal marker. ${ }^{28}$

In counterdistinction to Karaite, we know of no Hebrew-Aramaic words in Yiddish which have acquired new Slavic meanings, though rare cases can be cited where a Yiddish Hebraism has been readjusted to the form of the Yiddishism in a Slavic language, e.g. Yiddish kapen 'poor man' > Ukrainian (and Byslorussian?) Yiddish kapcan 'ragged fellow' $>$ Ukrainian Yiddish kapcán. ${ }^{29}$ As to periphrastic constructions with Hebrew components, Yiddish offers fewer examples of Slavic loan translations than Karaite, perhaps since Yiddish has only two productive auxiliaries, zayn 'be' in transitive constructions and vern 'become' in intransitive constructions - for which Slavic languages can offer no parallels..$^{30}$ A further reason why Hebrew-Aramaic elements in Yiddish tend not to undergo recalibration to Slavic models may be the fact that Yiddish provides unique grammatical patterns of integration for its Semitic components, e.g. the development of the periphrastic verbal conjugation is almost exclusively restricted to Hebrew participles. In Karaite, periphrastic constructions are available for Hebrew and Arabic participles, Arabic verbal nouns and Indo-European (mainly Slavic) infinitives, as well as nonverbal elements of any origin. ${ }^{31}$ As in Karaite, Yiddish periphrastic constructions with 'be(come)' are less open to Slavicization than constructions with other auxiliaries, e.g. Yiddish makrev zayn 'to sacrifice' (< Hebrew makriv 'sacrificing') is un-Slavicized vs. synonymous Slavicized Yiddish brengn a korbm (cited above). The difference in patterns of integrating Semitic elements in the two Jewish languages may also reflect a different chronology for the contact with Hebrew - e.g. the Hebrew adstratum in Karaite may be more recent than in Yiddish, say after the Slavicization process had taken place.

While Slavic patterns are often applied to native and Hebrew derivational patterns in Karaite, Yiddish offers examples where Semitic norms can maintain themselves in the face of Slavic influence. For example, the distribution and meanings of the Yiddish reflexive-reciprocal-middle pronoun $z i x$ are now essentially repatterned on the Slavic reflexive-reciprocal-middle-passive particle. Nevertheless, when Hebrew roots are involved, Hebrew grammatical requirements may determine the use of the Yiddish pronoun, even 
though the resulting pattern may have no support from the Slavic source grammars. An instance is Yiddish mištadl zayn (zix) 'intervene, intercede, lobby for' (< Hebrew mištadel 'trying') which optionally takes the pronoun zix since Hebrew participles of the hitpa'el type (in the participial form with mit-) often express a reflexive-reciprocal-middle-passive voice. The use of $z i x$ to respect the Hebrew grammatical category of voice parallels both German and Slavic practice, e.g. German sich verwenden, Byelorussian umiašacca. Yet, in Yiddish, since $z i x$ is optional, its presence can have no effect on the voice category of the simple periphrastic construction. In Slavic and German, on the other hand, the removal of the pronoun/particle entails a change from middle to active voice, e.g. German verwenden 'utilize', Byelorussian umiašać 'implicate'; the same is true for native Yiddish farvenden 'utilize': farvenden zix 'intercede for'. In spite of the Slavic model of umiašać (active): umiašacca (middle), the use of $z i x$ with the Hebrew root continues to be governed by the original voice category of the Hebrew participle.

\section{Integration of Slavic verbal stems in Karaite and Yiddish}

An interesting topic in both Karaite and Yiddish is the means by which the two target languages integrate Slavic verbal elements. The two languages differ radically in the selection and integration of Slavic verbal material. Karaite productively borrows Slavic verbal stems together with the Slavic infinitive endings which are then integrated periphrastically. For example, zrozumécét- (Ha) 'understand' < Polish zrozumieć, Byelorussian zrazumieć + Karaite ét'do, make'. Slavic stems are not given a Karaite infinitive suffix and conjugated in the native pattern. Karaite accepts Slavic infinitives in both their imperfective as well as perfective aspectual forms, though we have no examples of doublets; the choice of aspectual stems deserves further study. Thus, while perfective zrozumieć is accepted from Polish, there is no trace of the imperfective rozumieć. On the other hand, Karaite farbovat ét- (Tr, Ha) 'to paint' < Polish imperfective farbować, but there is no acceptance of the perfective zafarbować. ${ }^{32}$ While there are frequently formal differences between perfective and imperfective verb stems in Slavic, Karaite seems to neutralize these differences by dropping the vowels which express the aspect, e.g. vykorent ét- (Tr), vykorent' ét ( $\mathrm{Tr}, \mathrm{Ha})$, vykorént' ét- (Tr, Ha), vykorénc ét- (Ha) 'uproot' could be either from the Polish imperfective wykorzeniać or Byelorussian vykaraniać, or from the Polish perfective wykorzenić or Byelorussian vykaranić.

In cases where the Slavic infinitive requires a reflexive-reciprocalmiddle-passive particle, Karaite shows no less than three forms of integration: (1) Karaite often integrates the particle along with the verb stem, e.g. prekonaććet- 'become convinced' < Polish przekonać sie, straććet- 'make an effort'33 < Polish starać się, Byelorussian staracca (imperfective); (2) Karaite frequently omits the Slavic particle altogether, e.g. stracét-, staracét- $(\mathrm{Ha})$ 'make an effort', bavc ét- $(\mathrm{Tr})$ 'play, have a nice time' < Polish bawić się, Byelorussian 
bavicca, Ukrainian bavytysja, žén'c' ét $(\mathrm{Tr})$ 'get married' < Polish żenić się, Byelorussian žanicca. Omission of the reflexive-reciprocalmiddle-passive particle in Slavic usually creates a transitive verb Theoretically, Karaite might have expressed reflexivity through native derivational machinery, but there are apparently no instances of a borrowed Slavic verb stem taking a Karaite reflexive affix; (3) Karaite may substitute a native passive affix for the Slavic reflexive particle, presumably since in Slavic grammars the same morpheme can express passive, reciprocal, middle and reflexive actions, e.g. Byelorussian budavać 'build': budavacca 'be built' (passive) vs. apranać 'to dress': apranacca 'get dressed, dress oneself' (reflexive). For example, Karaite janč- (Tr) 'beat, knock, strike' appears with the passive -yl-as jančyl- 'be beaten, knocked; conquered'. In imitation of the Byelorussian practice of expressing passive, reflexive and middle actions by the same morpheme, Karaite apparently extends the non-passive function to the infix $-y l$-, so that jančyl-acquires the additional meaning of 'strike against, knock (on)' (on the model of Byelorussian bić, stukać 'knock, strike'; bicca, stukacca 'strike against, knock on'). ${ }^{34}$

Colonial German dialects parallel the Karaite practice of borrowing Slavic verb stems together with the infinitive and reflexivemiddle particle, e.g. Volga German barotsэ 'fight' < Russian borot'sja, Volga German staradsэ 'make an effort' < Russian starat'sja. ${ }^{35}$ These stems are conjugated on the native pattern. We have no examples of sich replacing the Slavic particle in Colonial German dialects.

In opposition to Karaite and Colonial German, the Yiddish analysis of Slavic morpheme structure is far more subtle. Yiddish only occasionally takes Slavic present tense stems, and always without the infinitive marker and reflexive-middle-passive particle; as in Karaite, the problem of choosing perfective or imperfective stems never arises for Yiddish speakers. While occasionally adopting Slavic verbal prefixes, Yiddish productively transfers the functions of the prefixes to native Yiddish verbal prefixes, e.g. Yiddish zahiken zix $\sim$ farhiken $z i x$ 'stutter' < Byelorussian zaikacca (the simplex is not used in Yiddish), čepen 'touch, bother, badger': farčepen začepen 'hook, snag, brush against' < Polish (za)czepiać. ${ }^{36}$

In Yiddish, because of the broad recalibration of native verbal prefixes to the functions of Slavic verbal prefixes, Hebrew-Aramaic roots may appear in derived or compound constructions which follow Slavic patterns of discourse; however, the Hebrew-Aramaic elements and the simplex verbs themselves do not ordinarily assume new Slavic functions. For example, Yiddish far- with the pronoun zix imparts the notion of 'be sunk in (action)' to a simple verb, as in troymen 'dream': fartroymen zix 'be sunk in dreams', patterned on Polish $z a-\ldots$ się or Byelorussian $z a-\ldots$ - ca, Polish marzyć 'dream': zamarzyć się 'be sunk in dreams', Byelorussian dumać 'think': zadumacca 'be sunk in dreams' (but German *sich verträumen). Yiddish also has a parallel construction with a Hebrew loan, farxolemen zix < xolem 'dream' (Hebrew xalom) (see also p. 103 above).

We may summarize this discussion by comparing the integration 
of Byelorussian (pa)staracca, Polish (po)starać się 'try, endeavour, make an effort' in Karaite, Colonial German and Yiddish. In this example, the verbal prefix, which serves to convert an imperfective verb into a perfective verb, is not borrowed by any of the three target languages; in the table below, the numeral 1 marks the present stem, 2 the infinitive suffix and 3 the reflexive-middle particle:

Table 1. The integration of Slavic verbal stems in Karaite, Colonial German and Yiddish

Byelorussian (pa)-stara-c-ca

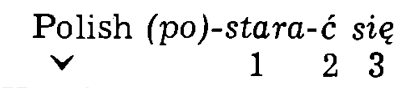

Karaite stara-ć-ć- + native auxiliary ét- 'do, make'>

$1 \quad 2 \quad 3$ staraććét-

Colonial German stara-d-ş conjugated as such with no native

$1 \quad 2 \quad 3$ auxiliary (Colonial German lacks a periphrastic conjugation altogether)

Yiddish stare- $\quad+$ native infinitive ending $-n$ and

$1 \quad z i x>$ staren $z i x$

A comparison of coterritorial Karaite, Yiddish and Colonial German in Eastern Europe shows that the two Jewish languages are far more receptive to Slavic influences than Colonial German, though both the duration and the nature of the contact are essentially identical for all three languages. In comparing Karaite and Yiddish responses to common Slavic sources of enrichment, we may observe that while the two Jewish languages are similar in their receptivity to non-native elements, they differ considerably in selection and integration:

(1) The Slavic impact in Karaite and Colonial German is mainly regional, while in Yiddish it is both regional and non-coterritorial.

(2) Slavic sources may merge in dialects of Karaite and Yiddish (we have no evidence from Colonial German).

(3) Of the two Jewish languages, only Yiddish innovates broadly in the use of its Slavic component.

(4) Slavic grammatical patterns in Karaite and Yiddish often serve as models for native patterns as well as for patterns introduced from Hebrew. The Slavicization of Colonial German tends to be haphazard and non-systemic.

(5) Hebrew components in Karaite may be Slavicized but apparently not in Yiddish.

(6) The Slavicization of Yiddish derivational morphology is far more subtle and penetrating than that of Karaite (and Colonial German) since it involves widespread calquing of Slavic derivational machinery 
without the productive transfer of the morphemes themselves. This is especially true of periphrastic verbal constructions consisting of a Semitic stem and a native auxiliary other than 'do, make' (periphrastic constructions with 'do, make' tend to resist Slavicization).

(7) Slavic morpheme structure is better respected in Yiddish than in Karaite or Colonial German.

(8) There has been only minor relexification of native and nonnative resources in Karaite and Yiddish to the Slavic surface cognates. We know of no examples of relexification to Slavic surface cognates in Colonial German.

\section{NOTES:}

1. The "Armenian" community in Eastern Europe was descended from Armenians who had assimilated to a Turkic dtalect prior to migrating to Eastern Europe. See A. Gawroński, 'Język Ormian polskich', in H. Ułaszyn, A. A. Krymski et al., Język polski $\imath$ jego historya $z$ uwzględnieniem innych języków na ziemiach polskich, part 2, Cracow, 1915, pp. 452-5; E. V. Sevortjan, ed., Dckumenty na poloveckom jazyke XVI v., Moscow, 1967. A dissenting view, that the Eastern European "Armenians" are descended from Turkic speakers who had converted to Christianity before migrating to Europe, is found in G. Clauson, 'Armeno-Qïpčaq', Rocznik orientalistyczny, 34, 2, 1971, pp. 7-13.

2. See T. Kowalski, Karalmische Texte im Dialekt von Troki, Cracow, 1929, p. xxiv.

3. In the Itogi vsesojuznoj perepisi naselenija 1970 goda, vol. 4, Moscow, 1973, pp. 22f?., the number of ethnic Karaites in the Soviet Union is given as 4,571, of whom only 585 gave Karaite as thetr native language. An indeterminable, but no doubt far smaller, number of speakers also reside in Poland and the West.

4. For discussion, see A. I. Dubinskij, 'Zametki o jazyke litovskich Tatar', Voprosy jazykoznanija, 1, 1972, pp. 82-9; our 'Jewish, Tatar and Karaite communal dialects and their importance for Byelorussian historical linguistics', JBS, III, 1, 1973, pp. 41-54 (with extensive bibliography); S. Akiner, 'The vocabulary of a Byelorussian Tatar K'it'ab in The British Museum', ibid., pp. 55-84 and 'Oriental borrowings in the language of the Byelorussian Tatars', The Slavonic and East European Review, 56, 2, 1978, pp. 224-41.

5. See Wł. Zajączkowski, 'Die bibliographischen Materialien zur Erforschung der karaimischen Sprache und Volkskunde', Folia orientalia, 1, 2, 1959, pp. 338-46; K. M. Musajev, Grammatika karaimskogo jazyka. Fonetika $i$ morfologija, Moscow, 1964 and Kratkij grammatičeskij očerk karaimskogo jazyka, Moscow, 1977.

6. In the discussions below we use the term Karaite exclusively in reference to the Eastern European dialects of the language, unless otherwise stated.

7. On the Slavicization of Karaite, see T. Kowalski, 'Pieśni obrzędowe w narzeczu Karaimów z Troki', Rocznik orientalistyczny, 3, 1925, p. 215 and Karaimische Texte im Dialekt von Troki, p. xxxviii; O. Pritsak, 'Das Karaimische', in Philologiac Turcicas Fundamenta, 1, Wiesbaden, 1959, pp. 338ff.; Musajev, Grammatika karaimskogo jazyka..., pp. 6, 21; A. Dubiński, 'Uber die slavischen Einfüsse in der karaimischen Sprache', Studia slavica, 15, 1969, pp. 139-44.

8. Examples from the two Karaite dialects of Trakai and Halyc are designated (Tr) ancl (Ha) respectively. All data are taken from the Karaimsko-russko-pol'skij slovar', Moscow, 1974, and given in the dictionary's transcription. In most recent periods, Karaites have been concentrated in the Vilna area, predominantly in Trakai (Troki) and Panevéžys (Ponieważ) and in Luck and Halyč. For a map of historical Karaite settlements, see A. Szyszman, 'Osadnictwo karaimskie i tatarskie na ziemiach W. Księstwa Litewskiego', Myśl Karaimska, 10, 1932-4, p. 7 (also separately, Vilna, 1936).

9. German dialects have been spoken in many areas of Eastern Europe for some six hundred years. See U. Weinreich, 'Yiddish and Colonial German in Eastern Europe: the differential impact of Slavic', American Contributions to the Fourth Internationct Congress of Slavicists, The Hague, 1958, pp. 369-419. For lack of data, we are obliged to ignore for the most part the Romani (Gypsy) dialects spoken on Byelorussian territory (see also note 22 below). 
10. We will ignore in the present paper the topics of reciprocal influences among the three languages as well as the differential impact of Baltic languages on Yiddish, German and Karaite; both topics need to be explored.

11. Weinreich, 'Yiddish and Colonial German...'.

12. For some brief remarks on palatalization in Karaite, Yiddish, Armeno-Kipčak and Romani due to contact with the surrounding slavic languages, see $\mathbf{R}$. Jakobson, Selected writings, 1, The Hague, 1962, pp. 140, 143, 167-8, 175, 189-90, 242-3, 408-9, containing the reprinted articles 'Uber die phonologischen Sprachbünde', Travaux du Cercle linguistique de Prague, 4, 1931, pp. 234-40; K charakteristike evrazijskogo jazykovogo sojuza, Paris, 1931; 'Sur la théorie des affinités phonologiques entre les langues', supplement to N. S. Troubetzkoy, Principes de phonologie, Paris, 1949, pp. 351-65; 'The Yiddish sound pattern and its Slavic environment' [in Yiddish], Yuda $A$. Yofe-bux, New York, 1958, pp. 207-20 (a Russian version appears in Selected writings, pp. 402-12). For additional studies of the Byelorussian (and general slavic) impact on Yiddish, see M. Sulman, 'Ab ahulnych elemientach u biełaruskaj i jaŭrejskaj movach', Potymia, 1926, 8, pp. 203-17; L. Vilenkin, Yidiser §praxatlas fun Sovetn-farband, Minsk, 1931; H. Sklar, 'Yiddish-Byelorussian linguistic parallels' [in Yiddish], Lingvistiše zamlung, 1, Minsk, 1933, pp. 65-80; U. Weinreich, 'The geographic makeup of Belorussian Yiddish', The Field of Yiddish, 3, The Hague-London-Paris, 1969, pp. 82-101; P. Wexler, 'A mirror image comparison of languages in contact: verbal prefixes in Slavicized Yiddish and Germanicized Sorbian', Linguistics, 82, 1972, pp. 89-123. Additional articles can be found in the Minsk Yiddish journals, Lingvistise zamlung, 1-3, 1933-6, and Caytšrift (far yidǐ̌er gešixte, demografye un ekonomik, literatur-foršung, spraxvisnšaft un etnografye), 1-5, 1926-31, and in The Field of Yiddish, 1, New York, 1954; 2-3. The Hague-London-Paris, 1965, 1969. For references to broader discussions of Slavic elements in Yiddish, see U. and B. Weinreich, Yiddish language and folklore. A selective bibliography for research, The Hague, 1959, pp. 24, 28.

13. For a brief comparison of the Turkic components in the Byelorussian speech of the Tatars and in Karaite, see N. A. Baskakov, 'Tjurkskije jazyki', Jazyki narodov SSSR, vol. 2, Moscow, 1966, pp. 7-8; Dubinskij, op. cit.

14. See Kowalski, 'Pieśni obrzędowe w narzeczu Karaimów z Troki', p. 217 and Karaimische Texte im Dialekt von Troki, p. XIV

15. ibid., p. XIVI.

16. M. Altbauer cites Byelorussian as a possible source for the intervocalic epenthetic labial segment found in both Karaite and Byelorussian Yiddish, e.g. Karaite luvax(lar) 'calendar' < Hebrew luax; Byelorussian Yiddish tuwes 'error' ( standard Yiddish toes) < Hebrew ta'ut (see his 'On the Hebrew pronunciation of the Lithuanian Karaites and on the Hebrew component in their language' [in Hebrew], Lesonenu, 22, TelAviv, 1958-9, p. 264 and 'Byelorussia' [in Hebrew], Haenciklopedia haivrit, 8, Jerusalem, 1963-42, col. 451). See Byelorussian navuka 'science' $\sim$ Russian nauka. However, the three languages do not agree on all the details of distribution (see standard Yiddish luex vs. Karaite luvax).

17. See Weinreich, 'Yiddish and Colonial German...', pp. 405-6.

18. See Weinreich, 'The geographic makeup of Belorussian Yiddish', p. 96.

19. See Weinreich, 'Yiddish and Colonial German...', p. 403 and 'The geographic makeup of Belorussian Yiddish', pp. 100-1; M. I. Herzog, The Yiddish language in Northern Poland. Its geography and history, Bloomington - The Hague, 1965, pp. 83, 258, 273; his 'Yiddish in the Ukraine: isoglosses and historical inferences', The Field of Yiddish, 3 , p. 58, fn. 3; E. Green, 'On accentual variants in the Slavic component of Yiddish', ibid., pp. 216-39.

20. Examples are from Weinreich, 'Yiddish and Colonial German...', pp. 405-6.

21. Both Karaite and Yiddish tend to replace Polish orthographic $r z[\check{z}$, s] by $r$ e.g. Karaite préstiré (Tr) '(bed)sheet' $(<$ [?] Polish prześcieradto), though there are exceptions, e.g. Yiddish cmentaž. Yiddish may even have occasional reflexes of $r z$, as in the placename pšedborž $(\sim$ pšedbož $)<$ Polish Przedbórz. According to Z. Stieber, the decomposition of $r>r \check{z}, r \breve{s}$ is typical of Polish dialect enclaves in Lvov and Ternopil (A historical phonology of the Polish language, Heidelberg, 1973, p. 109). For Yiddish data, see T. Gutman, 'On the fate of Polish $r z$ in Yiddish' [in Yiddish], Yidiše filologye, 1, nos. 4-6, Warsaw, 1924, pp. 382-6. We find the same preference for $r$ in Polish loans in Eastern Slavic languages, e.g. Byelorussian pacier(y) 'prayer' (plural only) < Polish pacierz; Ukrainian dvirec' 'railway station' < Polish dworzec (kolejo$w y$ ). Ukrainian has the same pattern with Czech loans, e.g. Ryhir 'Gregor' < Czech 
Rehor. To Judge from Weinreich's data, Colonial German dialects accept Polish $r z$ as such, e.g. Sompolno German przekornich 'concelted' < Polish przekorny ('Yiddish and Colonial German... $\quad$ p. 387). The choice of $r$ in most of the target languages need not indicate a very early borrowing from the period before Polish $r^{\prime}$ had developed through $\check{r}$ into $r z$ [ $\tilde{z}, \check{s}]$; rather, the target languages, for one reason or another, may have preferred not to avail themselves of the phonetically shortest path of integration. Stieber dates the change of Polish $r^{\prime}>\check{r}$ in the 13th century, $\check{r}>\check{z}, \check{s}$ in the late 14th century, but with $\check{r}$ still preserved until the 18th century (op. cit., pp. 49, 68-9). The presence of $\check{z}, \xi$ in Polish loans in Byelorussian seems to be a relatively recent stratum. For example, the 17th-19th-century Byelorussian and Polish texts of the Tatars in Arabic script generally use the grapheme $r$ for $r z$, except in some 19th-century texts where the grapheme $\mathcal{Z}$ is used (see A. K. Antonovic, 'Kratkij obzor belorusskich tekstov pisannych arabskim pis'mom', Poles'e, Moscow, 1968, p. 273). Doublets with $\check{z}, \xi, r \check{z} \sim r$ in Karaite and Yiddish should be systematically studied.

22. M. Sulman, 'Slavicisms in the vocabulary of Yiddish' [in Yiddish], Afn spraxfront, 3rd series, no. 3, Kiev, 1939, p. 82; see also Weinreich, 'Yiddish and Colonial German...', pp. 405-7. The differential impact of Polish on Eastern Slavic languages and on nonSlavic minority languages imported from Poland into Eastern Slavic milieux seems to be an unexplored topic. Like Yiddish and Karaite, Romani dialects in contact with Russian, Ukrainian and Byelorussian also manifest numerous Pollsh influences (in addition to the local Slavic Imprint), e.g. pancëxi (pl.) 'stockings' (Polish pończocha), zapléntynéspé té 'lose one's way' (Polish zabtązić [się] vs. Russian zabludit'sja), méncinés té 'torment' (Polish męczyć vs. Byelorussian mučyć: but see standard ancl Polish Yiddish mucn only). Romani examples are from M. V. Sergijevskij and A. P. Barannikov, Cygansko-russkij slovar', Moscow, 1938. We should also explore the posslbility that Polish influences are diffused secondarily among the target languages independent of Polish.

The geography of Slavic features frequently differs in Yiddish and Slavic, e.g sibilant confusion in Yiddish is of Slavic origin, but while the phenomenon characterizes Minsk Yiddish, as in remižnik 'wagon driver' it does not characterize Minsk Byelorussian ramiznik (< French remise) (example is from $M$. Horowitz, 'Yiddish in Belorussia' [in Yiddish], Yidiše sprax, 35, 1-3, New York, 1976, p. 64). On YiddishSlavic sibilant confusion, see Weinreich, 'Sábesdiker losn in Yiddish: a problem of linguistic affinity', Word, 8, 1952, pp. 360-77; 'Four riddles in bilingual dialectology', American Contributions to the Fifth International Congress of Slavicists, The Hague, 1963, pp. 335-59; P. Wexler, A historical phonology of the Belorussian language, Heidelberg, 1977, pp. 46, 109.

23. Polish Yiddish data are taken from I. Krakowski, Slownik polsko-żydowski, Warsaw. 1923.

24. See Weinreich, 'Yiddish and Colonial German...', p. 393.

25. Kurban rezac 'kill (animal) for sacrifle' (literally 'sacriflce' + Byelorussian 'cut'), recorded in the Byelorussian texts of the Tatars, seems to be a loan blend of Turkisb kurban kesmek (example from Akiner, 'Oriental borrowings...', p. 236).

26. Curiously, Turkish uses 'read' as the auxiliary in the compound dua okumak 'say a prayer', for which the Byelorussian Tatars have duai pec, literally 'sing' + 'prayer' (see Akiner, ibid.).

27. The reflex $d$ for Arabic $d$ contrasts with the reflex $z$ found in most Turkic languages, e.g. Turkish zebîha; $a>z$ in the Byelorussian of the Tatars as well (see V. Volski, 'Asnoŭnyja pryncypy arabskaf transkrypcyi biełaruskaha tekstu v "kitabach"', Uzvyšsa, 1927, 6, pp. 190-1).

28. In Dutch Yiddish, we flnd pilpelen, without the reflexive-middle pronoun, perhaps due to Dutch influence, since a reflexive-middle pronoun is not admitted with the Dutch verbs in this meaning (see H. Beem, Resten van een taal, Assen, 1967, p. 95). On the treatment of Semitic voice and aspectual categories in Hebrew and Arabic loans in Yiddish and Turkish, see our 'Periphrastic integration of Semitic verbal material in Slavicized Yiddish and Turkish', The Field of Yiddish, ed. M. I. Herzog et al., 4th collection, Philadelphia 1980, pp. 431-73.

29. See Sulman, 'Ab ahulnych elemientach...', p. 216; M. Weinreich, Gešixte fun der yidtšer šprax, IV, New York, 1973, p. 326.

30. See Wexler, 'Periphrastic integration of Semitic verbal material $\ldots$;.

31. For example, Karaite zabava ( $\mathrm{Tr}, \mathrm{Ha}$ ) 'fun, amusement' (< Byelorussian, Ukrainian 
zabava) may be Joined with ét- in the Halyc dialect to form 'play, have a nice time' - though the Ukrainlan accusative case marker is retained, e.g. zabavu ét-.

32. Note that the Polish infinitive marker $-c \hat{c}$ is replaced by $-t$ rather than $-c$ or $-c$ as in other examples. The possibility of multiple chronological stages in the borrowing process should be explored, though we should not exclude subsequent or even simultaneous Russian or Ukrainian interference - e.g. Ukrainian farbuvaty (the root is not found in Russian).

33. Cited in Dubiński's transcription, 'Uber die slavischen Einfüsse...', p. 142.

34. See also Musajev, Grammatika karaimskogo jazyka..., p. 252.

35. Weinreich, 'Yiddish and Colonial German...', p. 392.

26. See discussion of the Slavicization of Ylddish verbal prefixes in Wexler, 'A mirror image comparison...'. 